\title{
Description of Two Oxytrichid Ciliates (Ciliophora: Sporadotrichida: Oxytrichidae) Newly Reported from Korea
}

\author{
Choon Bong Kwon and Mann Kyoon Shin* \\ Department of Biological Science, College of Natural Sciences, University of Ulsan, \\ Ulsan 680-749, Korea
}

\begin{abstract}
To investigate the Korean ciliate fauna, two oxytrichid ciliates, Laurentiella strenua (Dingfelder, 1962) and Notohymena australis (Foissner and O'Donoghue, 1990) were collected from the Taehwa River in Ulsan, South Korea. These two ciliates are reported for the first time in Korea. Descriptions were based on the observation of live and silver stained specimens. Diagnoses of these species are as follows: Laurentiella strenua: body is approximately $320 \times 170 \mu \mathrm{m}$ in size, an inverted triangular shape. Cytoplasmic globules are present in both anterior and posterior margins, transparent and sized 10-15 $\mu \mathrm{m}$ in live specimens. Adoral zone of membranelles is covering about $50 \%$ of body length. Frontoventral-transverse cirri are arranged diagonally into 5 rows. Transverse cirri are arranged almost longitudinally and varied 4-6 in number. Dorsal kineties are 11 rows with multiple fragmentations. Macronuclei are 4-5 in number. Notohymena australis: body is approximately $170 \times 50 \mu \mathrm{m}$ in live specimens, slender and long ellipsoidal shape. Yellowish green cortical granules are present as pairs or rows which composed of 3-6 granules. Adoral zone of membranelles is covering about $36 \%$ of the body length, composed of 39-50 adoral membranelles. Dorsal kineties is 6 rows. Macronuclei are 2 in number.
\end{abstract}

Keywords: Laurentiella strenua, Notohymena australis, taxonomy, Taehwa River, morphology

\section{INTRODUCTION}

Two species of oxytrichid ciliates, representing two genera Laurentiella and Notohymena, which were not previously known in Korea, are investigated. Both genera are members of the family Oxytrichidae which has a basically large and distinctive somatic ventral ciliature as 18 frontoventral and transverse cirri (FVT) and 6 frontoventral primordial streaks in a division of morphogenesis. Up to now, more than 440 species were described worldwide in 45 oxytrichid genera, however, about 170 species are considered as valid (Berger, 1999; Lynn, 2008). Most oxytrichid genera including Notohymena show frontoventral cirri scattered anterior to midarea of ventral surface, however, some oxytrichid genera, such as Laurentiella and Onychodromus have conspicuous rows of frontoventral cirri which extend to mid-posterior surface (Lynn, 2008). Laurentiella has an increased number of FVT cirri which means the typical 18 FVT cirral pattern modified and deviated from basic cirral pattern independently (Foissner et al., 2004; Schmidt et al., 2007). Taxonomic position and status of L. strenua was unstable partly

\footnotetext{
*To whom correspondence should be addressed

Tel: 82-52-259-2396, Fax: 82-52-259-1694

E-mail: mkshin@ulsan.ac.kr
}

because their descriptions were poor and inaccurate. On the contrary to Laurentiella, genus Notohymena is one of typical members of Oxytrichidae. In Korea, 20 species of 11 oxytrichid genera have been described so far from freshwater, soil and marine habitats (Shin and Kim, 1988, 1993, 1994, 1996; Kwon and Shin, 2004, 2005, 2008; Jo et al., 2005; Gong and Choi, 2007; Gong et al., 2007). Two oxytrichid ciliates L. strenua and N. australis are newly described in this study with detailed illustrations and photographs to elucidate the Korean ciliate fauna.

\section{MATERIALS AND METHODS}

Sampling. The specimens of Laurentiella strenua and Notohymena australis were collected from two freshwater habi-

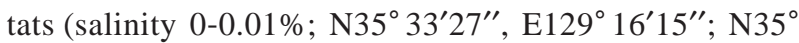
$\left.33^{\prime} 10^{\prime \prime}, \mathrm{E} 129^{\circ} 16^{\prime} 21^{\prime \prime}\right)$ in the Taehwa River located in Ulsan, South Korea. Samples were collected on August 27, 2007 and April 16, 2008 respectively. Water samples were taken from some water plants, algal mat, sands and detritus in the littoral zone of the river. The collected samples were moved to the laboratory, and maintained within a cool bag to prevent temperature rising. The ciliates were isolated from the 
raw culture in a petridish at room temperature.

Observation and staining. The shape and body size, food vacuoles, cytoplasm, oral apparatus and cortical granules were observed from live specimens. Silver impregnation was performed as described by Wilbert (1975) and Shin and Kim (1993). For further image processing, Adobe Photoshop 7.0 was used. Counts and measurements on silver impregnated specimens were conducted at a magnification of $\times 1,000$. Drawings of live specimens were based on free-hand sketches and using by Adobe Illustrator ver. 10. The classification scheme used was in accordance with that of Corliss (1979) and Lynn (2008).

\section{RESULTS AND DISCUSSION}

Subclass Stichotrichia Small and Lynn, 1985

Order Sporadotrichida Fauré-Fremiet, 1961

Family Oxytrichidae Ehrenberg, 1838

$1 *$ Genus Laurentiella Dragesco and Njine, 1971

$2 * 1$. Laurentiella strenua (Dingfelder, 1962)

(Figs. 1, 2 and Table 1)

Paruroleptus strenuus Dingfelder, 1962, 617; Czapic and Jordan, 1976, 284.

Laurentiella strenua: Berger and Foissner, 1989, 29.

Laurentia macrostoma Dragesco, 1966, 85; Borror, 1972, 14; Jankowski, 1979, 57.

Description. Body size $200-400 \times 70-200 \mu \mathrm{m}$, usually 320 $\times 170 \mu \mathrm{m}$, length: width about $2: 1$ in stained specimens. Body shape similar to an inverted triangular; anterior end wide, posterior narrowly rounded or tapered, posterior quarter strongly flattened and thus translucent (Figs. 1A, D, 2A). Ventral side flat and dorsal distinctly arched (Figs. 1G, 2C). Body rigid. Contractile vacuoles located in mid-body at the left margin of cell, at a level of buccal vertex, forming diastole with an anterior canal. Cytoplasm usually dark at low magnification due to numerous cytoplasmic crystals and food vacuoles (Figs. 1D, 2A); crystals sized about $1 \times 4$ $\mu \mathrm{m}$ and various shapes (Figs. 1E, 2D). The cytoplasmic globules very conspicuous, located in both anterior and posterior ends of the cell, $10-15 \mu \mathrm{m}$ in diameter, ring shaped, transparent and shining in live specimens (Figs. 1A, F, 2E). Cortical granules absent. Movement creeping on the substratum and swimming like a rotating board.

Buccal field and oral infraciliature: Buccal area very broad and deep like bowl-shaped (Fig. 1A). Adoral zone of membranelles covering about $50 \%$ of cell length with 54-75 ado- ral membranelles in impregnated specimens. Undulating membrane 100-150 $\mu \mathrm{m}$ long; the paroral and endoral membrane straight or slightly curved and arranged side by side, anterior end of paroral membrane slightly curved and dense (Figs. 1B, 2F, G).

Somatic infraciliature: Frontal cirri enlarged, $25 \mu \mathrm{m}$ long in size and 3 in number. Frontal-ventral-transverse cirral rows diagonally arranged and 5 in number; Leftmost cirral row (=first row) with 3 to 5 cirri excluding frontal and transversals, usually 4,2 th row with 3 to 7 cirri, usually 5 , 3 th row with 4 to 7 , usually 6 , 4th row with 8-12 cirri, usually 10 , rightmost row (=5th row) 9-13 cirri, usually 11 , sometimes anteriormost cirrus presented above 3 th row (Figs. 1B, 2F, G). Transverse cirri arranged almost longitudinally and varied from 4 to 6 , mostly 6 in number, slightly separated into two parts at posterior end of cell; one part composed of 3 cirri, located behind the 5th row and the other part composed of 3 cirri, located behind between the 3 th and 4th rows (Figs. 1B, 2B, F, G). One right and left marginal rows composed of 30-50 and 21-35 cirri, respectively. Both marginal rows nearly separated at the posterior end of body. Caudal cirri rather inconspicuous and 3 in number. Dorsal kineties more than 11 rows, complicated rows composed of approximately $4 \mu \mathrm{m}$ long bristles (Figs. 1C, $2 \mathrm{H}$ ).

Nuclear apparatus: Macronuclear nodules located between left side of undulating membrane and right of adoral zone of membranelles, ovoid to spherical form and usually 4 in number; anteriormost nodule $10-35 \times 5 \mu \mathrm{m}$ in stained specimens. Micronuclei adhering to macronucleus, $2-5 \mu \mathrm{m}$ in diameter and usually 1 to 4 in number (Figs. 1C, 2F-H).

Microhabitat. Detritus in littoral zone of river, salinity 0$0.01 \%$.

Distribution. Europe (Austria, France, Germany, Poland, Spain), Asia (Japan, Korea).

Remarks. Laurentiella strenua has a unique characteristic of having 5-7 frontal-ventral-transverse cirral rows among Oxytrichidae. The Korean population of $L$. strenua (Dingfelder, 1962) basically correlates well with the redescriptions of $L$. strenua by Czapic and Jordan (1976), Fedriani et al. (1976) and Szabó and Wilbert (1987), especially in respect to 5 frontal-ventral-transverse cirral rows, 4-8 transverse cirri, and 4 macronuclear nodules (Berger, 1999).

The Korean population of this species is slightly different from the population typified by Berger and Foissner (1989), but mostly could be regarded as being a variation of the arrangement of frontal-ventral-transverse cirral rows and the number of macronuclei in these populations.

Laurentiella strenua is similar to Stylonychia vorax in terms of large body, outline, wide anterior part and slightly

\footnotetext{
$1 *$ 역삼각하모충속, ${ }^{2 *}$ 역삼각하모충
} 

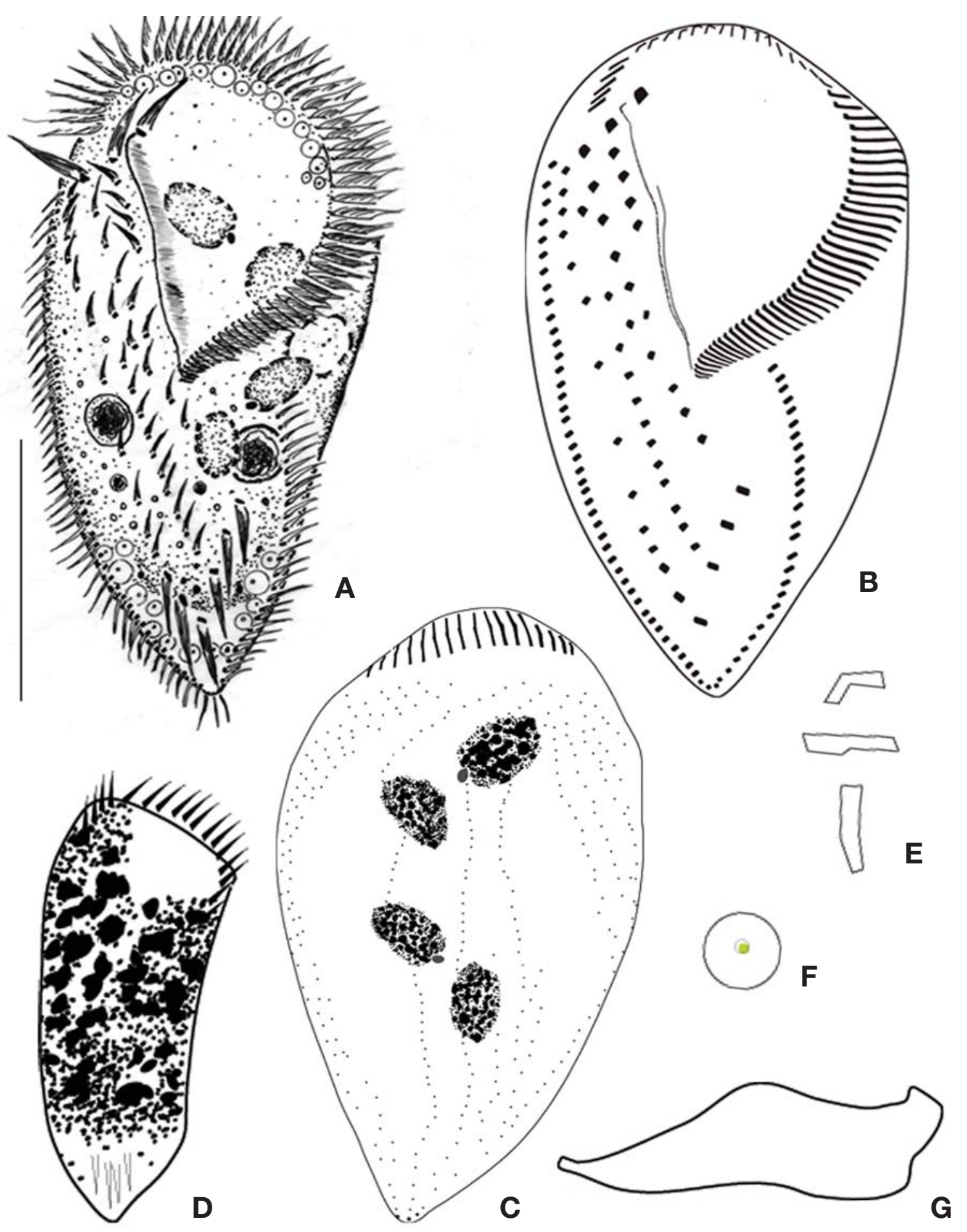

Fig. 1. Laurentiella strenua from live (A, D-G) and stained specimens (B, C). A. Ventral view of typical individuals; B and C. Infraciliature on ventral and dorsal side; D. Cytoplasm shown dark at low magnification; E. Cytoplasmic crystals; F. Shining cytoplasmic globules; G. Lateral view. Scale bar in $A=100 \mu \mathrm{m}$.

tapered posterior part only at low magnification. However, the distinctive differences between these two species are in the pattern of frontal-ventral-transverse cirral rows, the increased number of macronuclei and the non-prominent cau- 

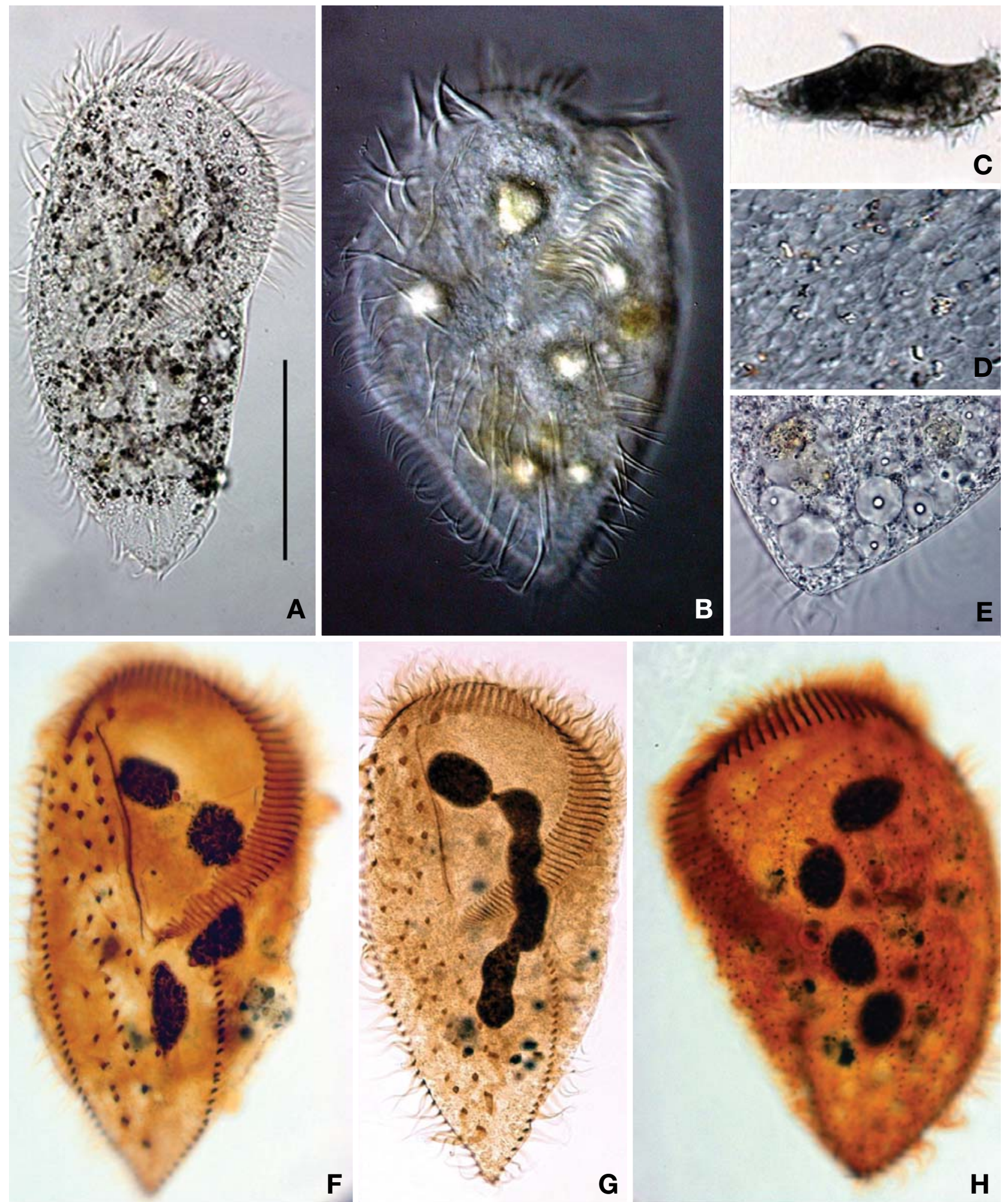

Fig. 2. Laurentiella strenua from live $(A-E)$ and stained specimens $(F-H)$. A. Ventral view of typical individuals; $B$. Somatic ciliary rows on ventral side; C. Lateral view; D. Cytoplasmic crystals; E. Cytoplasmic globules; F and G. Variations of ventral infraciliature; H. Dorsal kineties. Scale bar in $A=100 \mu \mathrm{m}$. 
Table 1. Morphometric data of Laurentiella strenua (Dingfelder, 1962) (Ls), Notohymena australis (Foissner and O'Donoghue, 1990) (Na)

\begin{tabular}{|c|c|c|c|c|c|c|c|c|c|}
\hline Characteristics & $\mathrm{p}$ & Mean & Med & Min & Max & SD & SE & CV & $\mathrm{n}$ \\
\hline Body, length in vivo & $\mathrm{Na}$ & 165 & 163 & 155 & 180 & 8.5 & 2.7 & 5.2 & 10 \\
\hline Body, width in vivo & $\mathrm{Na}$ & 50 & 50 & 40 & 70 & 8.2 & 2.6 & 16.3 & 10 \\
\hline Body length/width, ratio & $\mathrm{Na}$ & 3.4 & 3.4 & 2.4 & 3.9 & 0.4 & 0.1 & 12.4 & 10 \\
\hline \multirow[t]{2}{*}{ Body, length } & Ls & 315 & 300 & 200 & 400 & 37.4 & 6.6 & 12.5 & 32 \\
\hline & $\mathrm{Na}$ & 151 & 155 & 130 & 160 & 11.1 & 2.9 & 7.3 & 15 \\
\hline \multirow[t]{2}{*}{ Body, width } & Ls & 168 & 175 & 70 & 200 & 34.0 & 6.0 & 19.4 & 32 \\
\hline & $\mathrm{Na}$ & 54 & 50 & 40 & 70 & 7.4 & 1.9 & 13.6 & 15 \\
\hline \multirow[t]{2}{*}{ Body length/width, ratio } & Ls & 2 & 2 & 1 & 5 & 0.8 & 0.1 & 39.8 & 32 \\
\hline & $\mathrm{Na}$ & 3 & 3 & 2 & 4 & 0.5 & 0.1 & 16.5 & 15 \\
\hline \multirow[t]{2}{*}{ AZM, length } & Ls & 159 & 150 & 100 & 200 & 21.8 & 3.8 & 14.5 & 33 \\
\hline & $\mathrm{Na}$ & 54 & 55 & 40 & 63 & 5.8 & 1.5 & 10.7 & 15 \\
\hline \multirow[t]{2}{*}{ AZM/body length, ratio } & Ls & 51 & 50 & 33 & 75 & 7.1 & 1.2 & 14.1 & 32 \\
\hline & $\mathrm{Na}$ & 36 & 36 & 31 & 40 & 3.0 & 0.8 & 8.5 & 15 \\
\hline \multirow[t]{2}{*}{ AM, number } & Ls & 66 & 66 & 54 & 75 & 4.7 & 0.9 & 7.1 & 27 \\
\hline & $\mathrm{Na}$ & 43 & 43 & 39 & 50 & 3.9 & 1.0 & 9.1 & 14 \\
\hline Ma, number & Ls & 4 & 4 & 4 & 5 & 0.2 & 0.0 & 4.9 & 26 \\
\hline \multirow[t]{2}{*}{ Mi, number } & Ls & 2 & 2 & 1 & 4 & 0.9 & 0.2 & 43.3 & 25 \\
\hline & $\mathrm{Na}$ & 4 & 4 & 2 & 6 & 1.6 & 0.5 & 40.1 & 8 \\
\hline Cirral row 1 , number & Ls & 4 & 4 & 3 & 5 & 0.5 & 0.1 & 11.8 & 25 \\
\hline Cirral row 2, number & Ls & 5 & 4 & 3 & 7 & 1.0 & 0.2 & 25.0 & 25 \\
\hline Cirral row 3 , number & Ls & 6 & 6 & 4 & 7 & 1.0 & 0.2 & 15.9 & 24 \\
\hline Cirral row 4 , number & Ls & 10 & 10 & 8 & 12 & 1.0 & 0.2 & 10.1 & 25 \\
\hline Cirral row 5 , number & Ls & 11 & 11 & 9 & 13 & 1.2 & 0.2 & 10.8 & 23 \\
\hline \multirow[t]{2}{*}{ RMC, number } & Ls & 41 & 41 & 30 & 50 & 4.1 & 0.9 & 10.2 & 22 \\
\hline & $\mathrm{Na}$ & 36 & 38 & 30 & 41 & 4.3 & 1.4 & 11.8 & 1 \\
\hline \multirow[t]{2}{*}{ LMC, number } & Ls & 29 & 29 & 21 & 35 & 2.7 & 0.6 & 9.4 & 21 \\
\hline & $\mathrm{Na}$ & 36 & 35 & 31 & 46 & 4.2 & 1.3 & 11.7 & 10 \\
\hline \multirow[t]{2}{*}{ TC, number } & Ls & 6 & 6 & 4 & 8 & 0.8 & 0.2 & 13.1 & 20 \\
\hline & $\mathrm{Na}$ & 5 & 5 & 5 & 5 & 0.0 & 0.0 & 0.0 & 11 \\
\hline
\end{tabular}

The abbreviations in the table are as follows: $\mathrm{A}(\mathrm{Z}) \mathrm{M}=$ adoral (zone of) membranelles; $\mathrm{CV}=$ coefficient of variation in \%; $\mathrm{DK}=$ dorsal kineties; $\mathrm{FC}=$ frontal cirri; $M a=$ macronuclei; Max=maximum; Med=median; Mi=micronuclei; Min=minimum; $n=$ population size; $p=$ population; RMC and LMC=right and left marginal cirri; $\mathrm{SD}=$ standard deviation; $\mathrm{SE}=$ standard error; $\mathrm{TC}=$ transverse cirri.

dal cirri. This species is regarded as a monotypic species, because different species, Paruroleptus strenuous Dingfelder, 1962, Laurentia macrostoma Dragesco, 1974 and Onychodromus acuminatus Fedriani, Torres, Pérez-Silva, 1976, and all congeners were synonymized by Berger and Foissner (1989) and Berger (1999).

Family Oxytrichidae Ehrenberg, 1838

$1 *$ Genus Notohymena Blatterer and Foissner, 1988

\section{2*2. Notohymena australis (Foissner and} O’ Donoghue, 1990) (Figs. 3, 4, 5 and Table 1)

Oxytricha australis Foissner and O'Donoghue, 1990, 689.

Notohymena australis: Blatterer and Foissner, 1988, 68; Berger, 1999, 340.

Description. Body size $155-180 \times 40-70 \mu \mathrm{m}$, usually $170 \times$ $50 \mu \mathrm{m}$, length: width 3.4: 1 on average in live specimens. Body slender and long ellipsoidal, sometimes slightly ovoid; anterior end rounded with distinct collar, sometimes bent leftward, posterior end rounded, slightly converging posteriorly, usually parallel in mid of left and right sides but slightly vaulted on left margin at level of contractile vacuole; ventrally flat, dorsally slightly convex (Figs. 3A, D, G, 4A-C, H). Body soft and flexible (Fig. 4G). Contractile vacuole slightly above mid-body at left margin of cell, without distinct collecting canals. Cytoplasm transparent, appeared dark brown at low magnification, with many refractive cytoplasmic globules distributed below postoral region, filled with large, many shining globules (Figs. 3E, 4B, D). Food vacuoles containing various diatoms (Fig. 5C). Cortical granules yellowishgreen and mostly along cirral rows on ventral and dorsal side; each granule measured at $0.5-1 \mu \mathrm{m}$ across, composed of 3-6 granules in pairs or a row (Figs. 3F, 4E, F, 5D). Movements creeping on the bottom.

Buccal field and oral infraciliature: Buccal area moderately narrows, but deep, curved semicircular at anterior portion. Adoral zone of membranelles covering $36 \%$ of body length

$1 *$ 갈고리막하모충속, ${ }^{2 *}$ 많은꼬리갈고리막하모충 

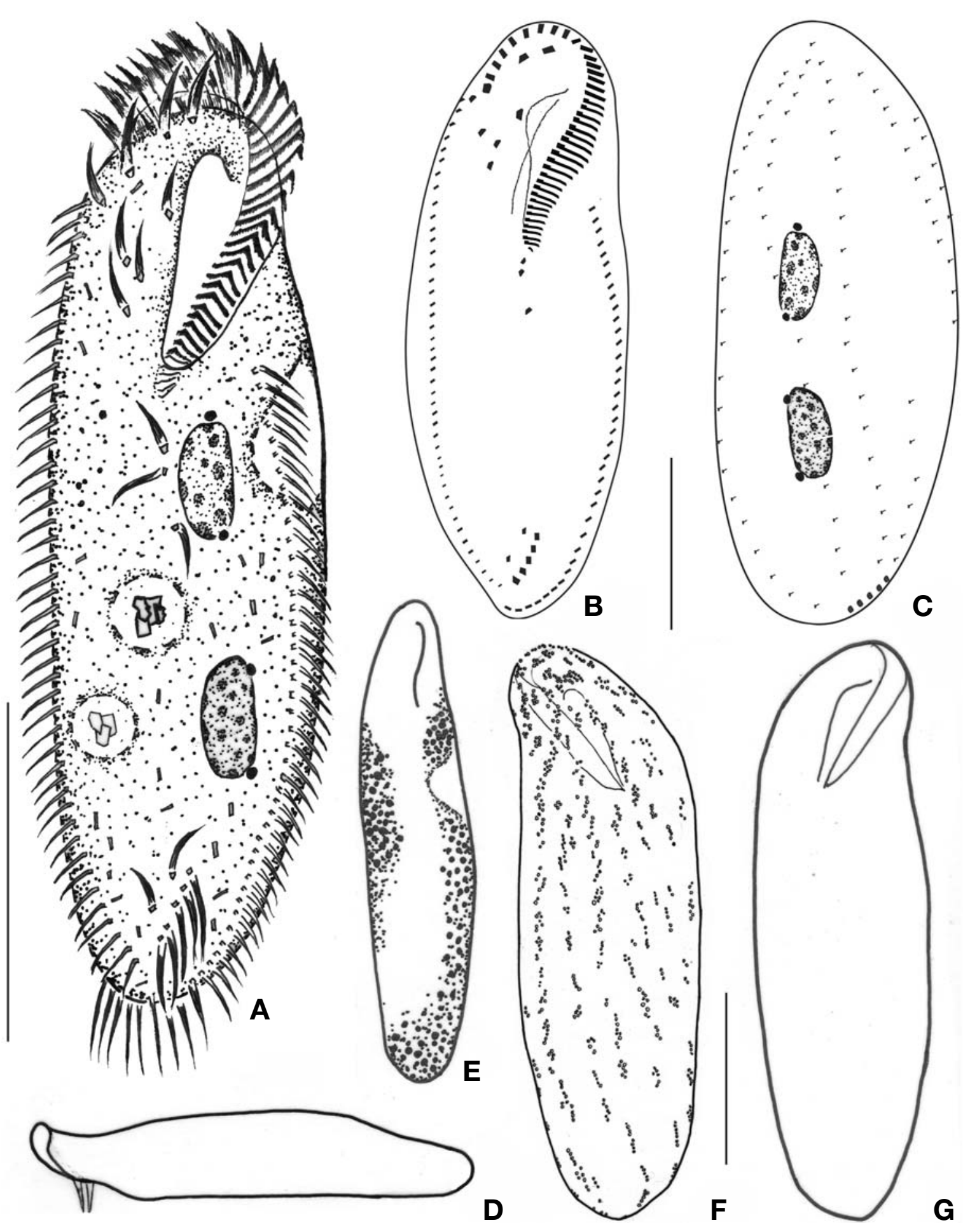

Fig. 3. Notohymena australis from live (A, D-G) and stained specimens (B, C). A. Ventral view; $B$ and $C$. Infraciliature on ventral and dorsal side; D. Lateral view; E. Cytoplasm at low magnification; F. Cortical granules on dorsal side; G. Body shape bent leftward anterior. Scale bars in $A, B, F=50 \mu \mathrm{m}$.

composed of 39-50 adoral membranelles in stained specimens. Undulating membrane ordinary Notohymena pattern; distal end of paroral membrane hook-like shape (Figs. 3B, $5 \mathrm{~A}, \mathrm{C})$. 

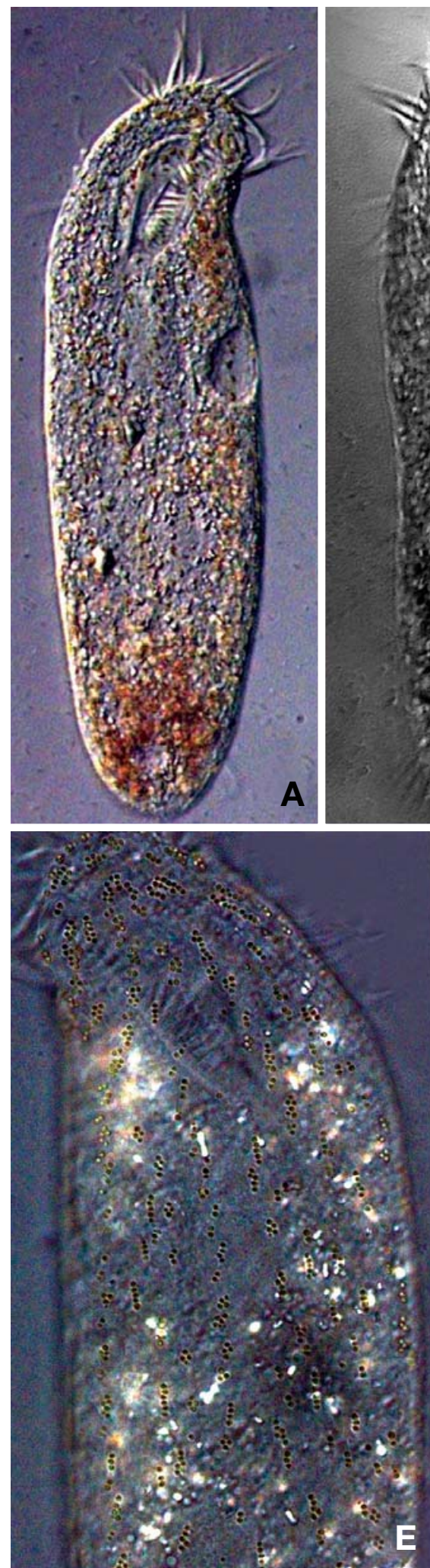
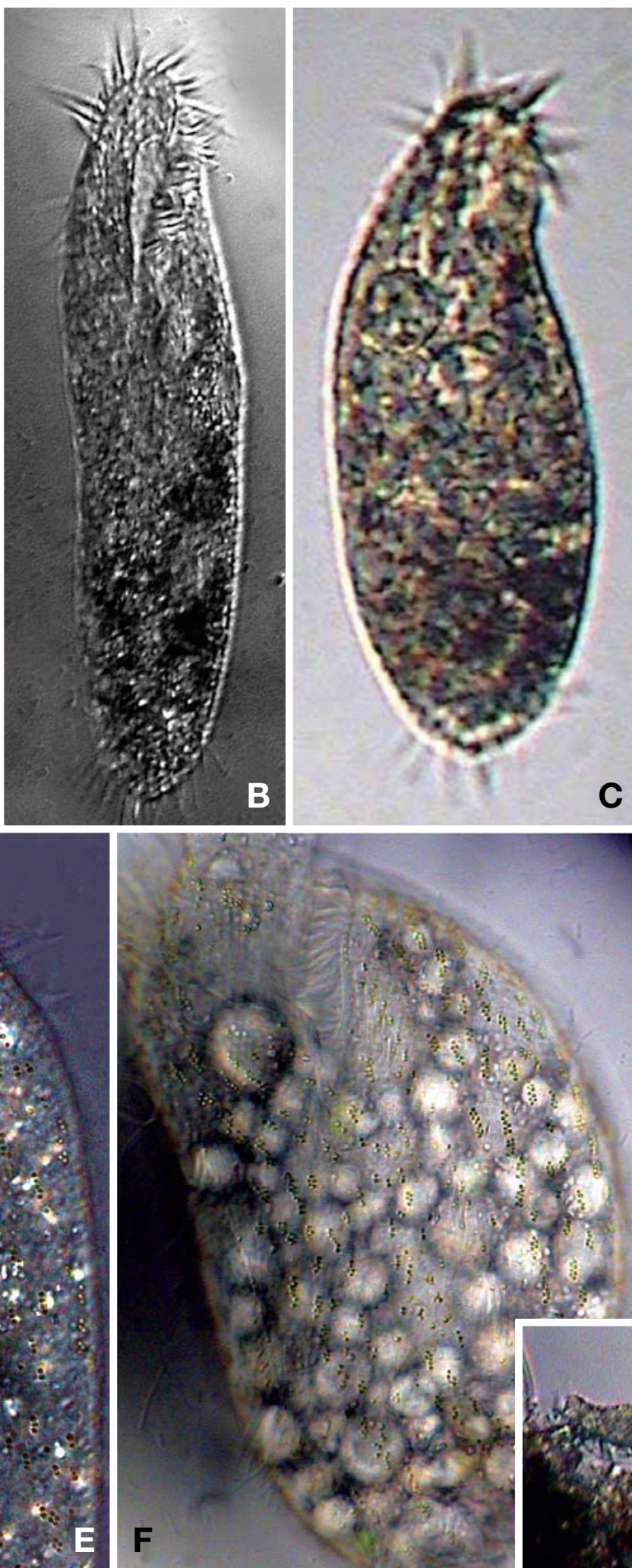

C
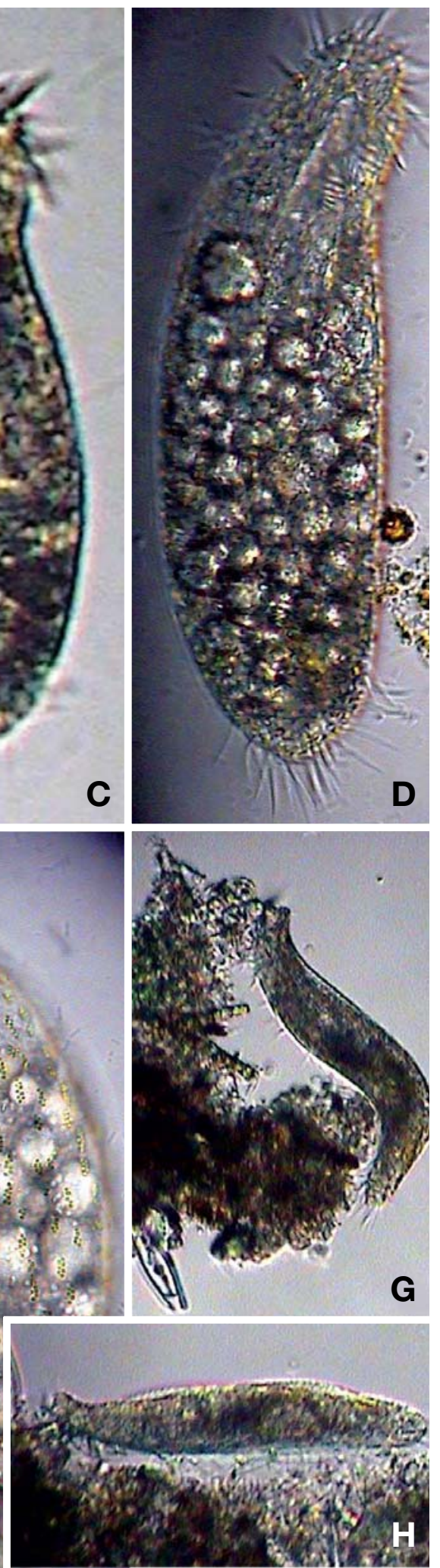

Fig. 4. Notohymena australis from live specimens. A, B, C. Ventral view and various body shapes; D. Greasily cytoplasm with shining globules; E and F. Cortical granules at dorsal and ventral side; G. Flexible body; H. Lateral view. 


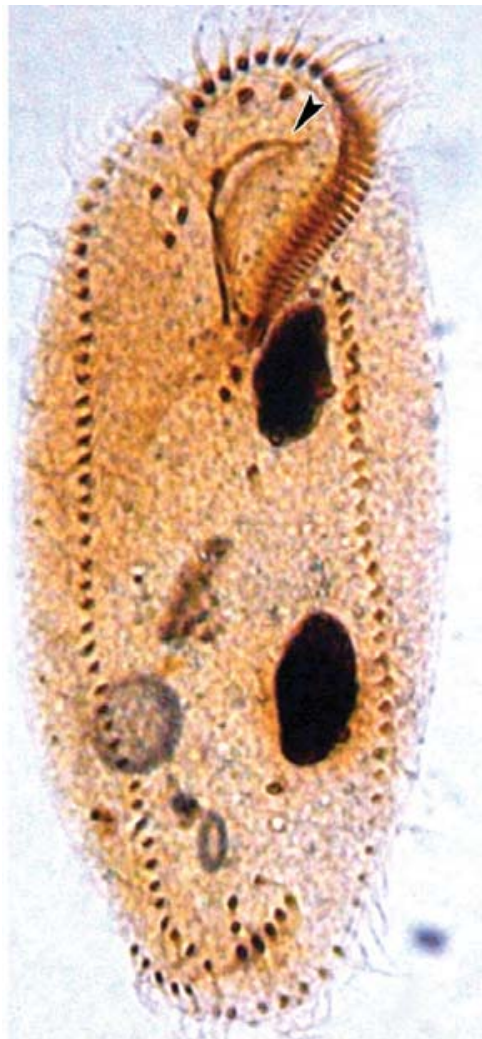

A
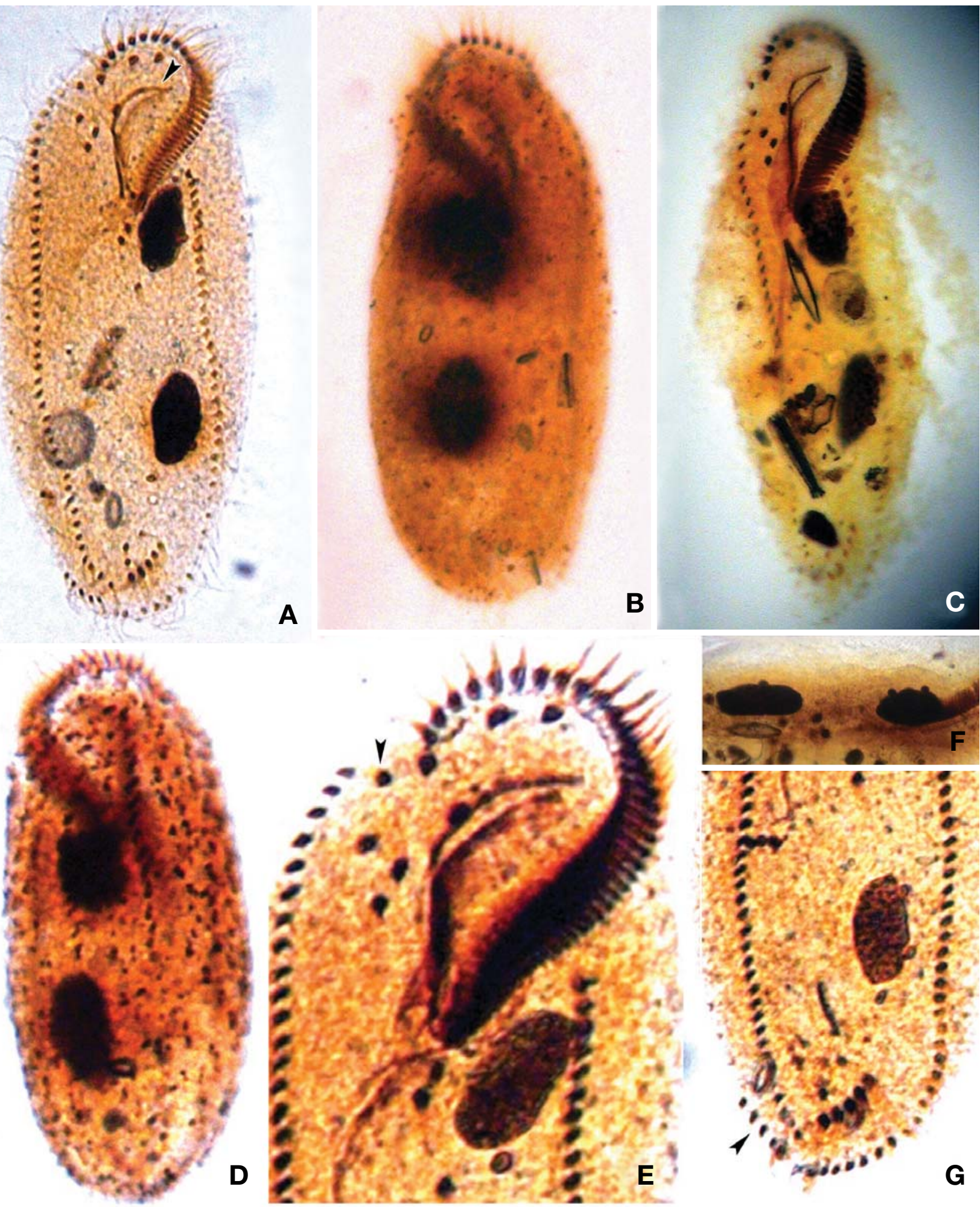

Fig. 5. Notohymena australis from stained specimens. A and B. Infraciliature on ventral and dorsal sides (Arrowhead in A denotes hook like distal end of paroral membrane); C. Food vacuoles with various diatoms; D. Cortical granules on dorsal surface; E. Infraciliature and undulating membranes at frontal region. Arrowhead denotes anteriormost frontoventral cirrus; F. Nuclear apparatus; G. Pre-transverse cirri, left and right marginal cirri and caudal cirri (arrowhead). 
Somatic infraciliature: Frontal cirri enlarged and 3 in number. Buccal cirrus right of paroral membrane. Frontoventral cirri 4 in number: Anteriormost one separated the other 3 frontoventral cirri (Fig. 5E arrowhead). Postoral ventral cirri 3 in number. Pre-transverse cirri 2 in number. Transverse cirri oblique J-shaped, each cirrus approximately $25 \mu \mathrm{m}$ long in live, 5 in number. One right and 1 left marginal rows composed of 30-41 in right and 31-46 cirri in left row; both marginal rows distinctly separated posterior, usually left marginal row extended to right corner of posterior end and each cirrus approximately $10 \mu \mathrm{m}$ long in live specimens. Dorsal kineties 5 to 6 rows with bristles (Figs. 3C, 5B). Caudal cirri conspicuous in live state, located dorsally on the gap between both marginal rows, about $20 \mu \mathrm{m}$ long, 5 to 7 in number (Fig. 5A, G).

Nuclear apparatus: Macronuclear nodules located close together in middle of cell, anterior one measured $20 \times 10$ $\mu \mathrm{m}$ in protargol specimens, ellipsoidal or oval shape, 2 in number. Micronuclei adhered to macronuclear nodules, ellipsoidal shape, sized about $3 \times 2 \mu \mathrm{m}$ and 2 to 6 , usually 4 in number (Fig. 5A, F).

Microhabitat. Detritus and sand in littoral zone of river, salinity $0.01 \%$.

Distribution. Europe (Germany), Australia, Asia (Korea).

Remarks. The Korean population of Notohymena australis (Foissner and O'Donoghue, 1990) basically agrees with original description and subsequent redescriptions in terms of the number of caudal cirri and the color of cortical granules. The number of postoral cirri in Korean population is different from that of original description, however, there are some variations in it (Berger, 1999). A redescription of European population by Gschwind (1991) is almost identical to that of Korean population especially in body size, number of right and left marginal cirri, while the pattern and arrangement of cortical granules in both populations are slightly different. In Korean population, 3-6 granules are arranged in pairs or rows along the cirri and dorsal kineties, however, in European and Australian populations, 4-10 granules were arranged into a small cluster around cirri and dorsal bristles (Foissner and O’Donoghue, 1990; Gschwind, 1991).

This species, Notohymena australis, resembles N. antarctica Foissner, 1996 in having yellow or yellowish-green cortical granules, however, the former differs from the latter as follows: 1) the number of marginal cirri (30-41 vs. 15-19 in right; $31-46$ vs. 15-24 in left marginal cirri); 2) the number of caudal cirri (5-7 vs. 3 ).

This species is also similar to Notohymena saprai Kamara and Kumar, 2008 in body size, however, the former differs from the latter by color of cortical granules (yellowish-green vs. dark green), number of macronuclei (2 vs. 2-5) and cau- dal cirri (5-7 vs. 3) (Kamara and Kumar, 2008).

This species is similar to Cyrtohymena australis in 18 fronto-ventral-transverse cirral pattern, dorsal kineties and yellowish cortical granules, however, the pattern of undulating membrane and shape of adoral zone of membranelles distinguish clearly between these two species (Berger, 1999).

\section{ACKNOWLEDGEMENTS}

This work was supported by the 2009 Research Fund of University of Ulsan.

\section{REFERENCES}

Berger, H., 1999. Monograph of the Oxytrichidae (Ciliophora, Hypotrichia). Monographiae Biol., Kluwer Academic Publishers, pp. 1-722.

Berger, H. and W. Foissner, 1989. Morphology and biometry of some soil hypotrichs (Protozoa, Ciliophora) from Europe and Japan. Bull. Br. Mus. nat. Hist. (Zool)., 55: 19-46.

Blatterer, H. and W. Foissner, 1988. Beitrag zur terricolen Ciliatenfauna (Protozoa: Ciliophora) Australiens. Stapfia., 17: 1-84.

Borror, A.C., 1972. Revision of the order Hypotrichida (Ciliophora, Protozoa). J. Protozool., 19: 1-23.

Corliss, J.O., 1979. The Ciliated Protozoa. Characterization, Classification and Guide to the Literature (2nd ed). Pergamon Press, Oxford, New York, Toronto, Sydney, Paris, Frankfurt, 455pp.

Czapic, A. and A. Jordan, 1976. Les observations sur les ciliés d'une mare. Acta Protozool., 15: 277-288.

Dingfelder, J.H., 1962. Die Ciliaten vorübergehender Gewässer. Arch. Protistenkd., 105: 509-658.

Dragesco, J., 1966. Ciliés libres de Thonon et ses environs. Protistologica, 2: 59-95.

Fedriani, C., A. Torres and J. Pérez-Silva, 1976. Laurentia acuminate n. sp.-Boln R. Soc. Esp. Hist. nat., 74: 67-74.

Foissner, W., S.Y. Moon-van der Staay, G.W.M. van der Staay, J.H.P. Hackstein, W.D. Krautgartner and H. Berger, 2004. Reconciling classical and molecular phylogenies in the stichotrichines (Ciliophora, Spirotrichea), including new sequences from some rare species. European J. Protistol., 40: 265-281.

Foissner, W. and P.J. O’Donoghue, 1990. Morphology and infraciliature of some freshwater ciliates (Protozoa, Ciliophora) from Western and South Australia. Invertebr. Taxon, 3: 661-696.

Gong, J. and J.K. Choi, 2007. A new marine ciliate, Tachysoma multinucleata sp. nov. (Ciliophora: Oxytrichida). J. Mar. Biol. Ass. U.K., 87: 1081-1084.

Gong, J., S.J. Kim, S.Y. Kim, G.S. Min, D.M. Roberts, A. Warren and J.K. Choi, 2007. Taxonomic redescription of two 
ciliates, Protogastrostyla pulchra, n. g., n. comb. and Hemigastrostyla enigmatica (Ciliophora: Spirotrichea, Stichotrichia), with phylogenetic analyses based on $18 \mathrm{~S}$ and $28 \mathrm{~S}$ rRNA gene sequences. J. Eukaryot. Microbiol., 54: 468478.

Gschwind, K., 1991. Morphologie und Infraciliatur einiger limnischer Ciliaten (Protozoa: Ciliophora). Diplomarbeit Universität Salzburg, 115pp.

Jankowski, A.W., 1979. Revision of the oder Hypotrichida Stein, 1859. Generic catalogue, phylogeny, taxonomy. Trudy zool. Inst., Leningrad, 86: 48-85.

Jo, J.O., Y.U. Kim and M.K. Shin, 2005. Redescription of three newly recorded Gastrostyla ciliates (Ciliophora: Sprirotrichea: Stichotrichida) with morphological variations from Korea. Korean J. Syst. Zool., 21(1): 45-56.

Kamra, K. and S. Kumar, 2008. Notohymena saprai sp. nov, a new oxytrichid ciliate (Protozoa, Ciliophora) from the valley of flowers, a Himalayan bioreserve region; description and morphogenesis of the new species. Indian J. Microbiol., 50: 33-45.

Kwon, C.B. and M.K. Shin, 2004. Two newly recorded ciliates, Oxytricha balladyna and O. longa (Ciliophora: Spirotrichea: Sporadotrichida) from Korea. Korean J. Syst. Zool., 20: 171-178.

Kwon, C.B. and M.K. Shin, 2005. Redescription of two terrestrial hypotrichous ciliates from Jindo Island, Korea. Korean J. Syst. Zool., Special Issue 5: 71-76.

Kwon, C.B. and M.K. Shin, 2008. Two newly recorded ciliates, Oxytricha longigranulosa and O. marina (Ciliophora: Spirotrichea: Sporadotrichida) from Korea. Korean J. Syst. Zool., 24(1): 81-88.

Lynn, D.H., 2008. The Ciliated Protozoa. Characterization, Classification and Guide to the Literature (3rd ed). Springer Science, New York, Toronto, Sydney, Paris, Frankfurt, pp. 1-605.

Schmidt, S.L., D. Bernhard, M. Schlegel and W. Foissner,
2007. Phylogeny of the Stichotrichia (Ciliophora; Spirotrichea) reconstructed with nuclear small subunit rRNA gene sequences. Discrepancies and accordances with morphological data. J. Eukaryot. Microbiol., 54: 201-209.

Shin, M.K. and H.S. Kim, 1988. Several hypotrichous ciliates inhabiting the Han River in Seoul Korea. Korean J. Syst. Zool., Special Issue 2: 67-85.

Shin, M.K. and W. Kim, 1993. New records of three oxytrichid hypotrichs (Ciliophora: Hypotrichida: Oxytrichidae) from the Han River in Seoul, Korea. Korean J. Zool., 36: 223230.

Shin, M.K. and W. Kim, 1994. Morphology and biometry of two oxytrichid species of genus Histriculus Corliss, 1960 (Ciliophora, Hypotrichida, Oxytrichidae) from Seoul, Korea. Korean J. Zool., 37: 113-119.

Shin, M.K. and W. Kim, 1996. Terrestrial hypotrichous ciliates from Chindo Island, Korea. Korean J. Syst. Zool., 12: 1724.

Stiller, J., 1974a. Ergäzungen der von Fauré-Fremiet vorgenommenen Neuordnung der Hypotrichen Ciliaten. Ann. Hist. Nat. Mus. Nat. Hung., 66: 129-133.

Stiller, J., 1974b. Járólábacskás csillósok. Hypotrichida. Fauna Hung., 115: 1-187.

Szabó, A. and N. Wilbert, 1987. Adatok a Laurentiella acumnaata Fedriani et al. 1976 (Ciliophora, Hypotrichida) magyarországi elöfordulásához és ökologiájához. Debrceni Agrártudományi Egyetem Tudományos Közlem ényei, 27: 439451.

Tuffrau, M., 1987. Proposition d'une classification nouvelle de I'ordre Hypotrichida (Protozoa, Ciliophora), fondée sur quelques données récentes. Annal. Sci. Natur. Zool. Paris, 8: 111-117.

Wilbert, N., 1975. Eine Vertesserte Technik der Protargoimpragnation fur Ciliaten. Mikrokosmos, 64: 171-179.

Received November 3, 2010 Accepted November 12, 2010 